\title{
Penerapan Re Order Point (Rop) Dan Safety Stock Pada Pengadaan Chemical Demulsifier dan Chemical Reverse Demulsifier
}

\author{
Muhammad Ihsan Hamdy ${ }^{1}$, Ahmad Masari ${ }^{2}$, Muhammad Fajri Ardi ${ }^{3}$ \\ 1,2,3 Program Studi Teknik Industri, Fakultas Sains dan Teknologi, UIN Sultan Syarif Kasim Riau \\ Jl. HR. Subrantas No. 155 Simpang Baru, Pekanbaru, 28293 \\ Email: m.ihsanhamdy@uin-suska.ac.id,ahmad.mas’ari@uin-suska.ac.id
}

\begin{abstract}
ABSTRAK
Pengadaan material chemical belum menggunakan metode yang baku, pengadaan masih dilakukan menggunakan perhitungan berdasarkan perkiraan dan kurangnya pengontrolan terhadap persediaan material chemical didalam gudang. Sebuah perusahaan juga memerlukan pengendalian persediaan material. Masalah pemesanan material merupakan hal yang penting dalam suatu perusahaan, sehingga malasah ini terus dipelajari dan dikembangkan. Metode yang digunakan untuk mengatasi masalah tersebut yaitu Re Order Point (ROP) dan Safety Stock. Metode ini digunakan untuk menentukan titik pesan kembali untuk material demi kelancaran proses produksi perusahaan. Tujuan penilitian ini adalah untuk mengetahui titik ROP dan Safety Stock material chemical. Hasil Penelitian ini yaitu ROP chemical demulsifier 460 liter dan ROP chemical revers demulsifier 920 liter. Safety Stock cehmical demulsifier 161 liter dan chemical revers demulsifier 437 liter.
\end{abstract}

Kata Kunci: Re order Point, Safety Stock, chemical Demulsifier, chemical Reverse Demulsifier, dan Penyimpanan

\section{Pendahuluan}

Pada sebuah perusahaan yang bergerak dalam bidang eksplorasi minyak bumi terdapat proses yang menggunakan cairan kimia. Salah satu cairan kimia yang digunakan adalah demulsifier dan reverse demulsifier. Cairan kimia ini berfungsi sebagai reaksi pemisah antara minyak bumi dengan unsur pengotor.

Pemesanan cairan kimia ini dilakukan secara berkala kemudian disimpan didalam gudang sebelum digunakan. Seharusnya, jumlah pesanan sudah disesuaikan dengan kebutuhan untuk beberapa waktu kedepan. Adakalanya terjadi kondisi dimana cairan kimia yang dipesan sebelumnya masih bersisa namun datang lagi pesanan yang baru. Hal ini menyebabkan terjadi penumpukan cairan kimia di gudang penyimpanan.

Cairan kimia demulsifier dan reverse demulsifier dikemas didalam sebuah drum dan disimpan di dalam gudang. Saat terjadi stok berlebih sebagian cairan kimia diletakkan diluar gudang pada kondisi ruang terbuka. Pada kondisi tersebut cairan kimia akan terpapar hujan dan panas yang dapat menyebabkan penurunan kualitas. Jika demikian maka cairan kimia tersebut tidak dapat digunakan lagi.

Melihat dampak yang ditimbulkan maka kelebihan stok cairan kimia ini perlu dihindari. Cara menghindarinya adalah dengan melakukan pemesanan ulang untuk stok berikutnya pada waktu yang tepat. Melalui cara seperti ini maka stok yang baru akan datang setelah stok yang sebelumnya akan habis.

\section{Tinjauan Pustaka}

\section{Re Order Point}

Re order Point adalah tingkat persediaan dimana pemesanan kembali harus dilakukan. Model persediaan mengasumsikan bahwa suatu perusahaan akan menunggu sampai tingkat persediaannya mencapai nol sebelum perusahaan memesan kembali dan dengan seketika kiriman yang dipesan akan diterima.

Waktu antara dilakukannya pemesanan atau waktu pengiriman biasa cepat atau lambat, sehingga perlu ditetapkan metode pemesanan kembali. Apabila ROP terlambat maka berakibat munculnya biaya kekurangan bahan (stock out cost) dan bila ROP terlalu cepat makan akan 
berakibat timbulnya biaya tambahan (extra carrying cost) (Lukmana dan Trivena, 2015).

Perusahaan - perusahaan menetapkan kebijakan dalam menentukan titik pemesanan ulang, sebagai berikut: ((Lukmana dan Trivena, 2015).

a. Menetapkan jumlah pengggunaan selama lead time, yaitu waktu mulai barang dipesan sampai barang datang ditambah persentase tertentu sebagai persediaan pengaman.

b. Menetapkan jumlah penggunaan selama lead time ditambah penggunaan selama periode tertentu sebagai safety stock.

c. Penetapan lead time dengan biaya yang ekonomis atau minimum.

\section{Safety Stock}

Stock pengaman merupakan persediaan tambahan yang diadakan untuk melindungi atau menjaga kemungkinan terjadinya kekurangan bahan atau stock out (Ikhwanina, 2017). Saat ini, pengendalian persediaan didasarkan pada pengalaman periode sebelumnya. Untuk mengantisipasi tingginya fluktuasi permintaan produk, perusahan menyediakan persediaan pengaman (safety stock) untuk tiap produk sebanyak $30 \%$ dari selisih antara nilai rata-rata barang masuk (pembelian) dan barang keluar (penjualan) pada periode tertentu. Perhitungan persediaan cadangan didasarkan data permintaan tahun sebelumnya dan metode pengendalian ini berlaku untuk seluruh jenis produk.

Hal lain yang belum diperhatikan perusahaan adalah penentuan waktu pemesanan kembali. Penentuan titik pemesanan kembali, dilakukan dengan memperkirakan waktu pesan dengan waktu kedatangan barang (lead time). Perbedaan waktu antara saat memesan sampai saat barang datang dikenal dengan istilah lead time (Kushartini dan Almahdy, 2015). Namun, belum mempertimbangkan potensi kenaikan permintaan yang memungkinkan terjadinya kehabisan barang (stock out) yang harus dihindari (Pulungan dan Fatma, 2018).

\section{Metode Penelitian}

Pengolahan data pada penelitian ini adalah menghitung re order point dan safety stock. Re order point dihitung dengan rumus sebagai berikut:

$\mathrm{ROP}=(\mathrm{LDxAU})+\mathrm{S}$

$\mathrm{LD}=$ lead time (waktu tunggu pesanan)

$\mathrm{AU}=$ kebutuhan rata rata

$\mathrm{SS}=$ safety stock
Sedangkan safety stock dihitung dengan rumus sebagai berikut:

$\mathrm{SS}=$ (pemakaian maks-pemakaian rata rata) $\mathrm{x}$ lead time

\section{Hasil dan Pembahasan}

Berikut adalah data-data yang digunakan dalam penelitian ini:

Tabel 1. Penggunaan chemical demulsifier

\begin{tabular}{|c|c|c|}
\hline \multirow[t]{2}{*}{ Bulan } & \multicolumn{2}{|c|}{ Jumlah } \\
\hline & Liter & Drum \\
\hline Januari & 400 & 2 \\
\hline Februari & 600 & 3 \\
\hline Maret & 800 & 4 \\
\hline April & 1000 & 5 \\
\hline Mei & 400 & 2 \\
\hline Juni & 600 & 3 \\
\hline Juli & 800 & 4 \\
\hline Agustus & 800 & 4 \\
\hline September & 400 & 2 \\
\hline Oktober & 600 & 3 \\
\hline November & 1000 & 5 \\
\hline Desember & 400 & 2 \\
\hline Total & 7800 & 39 \\
\hline
\end{tabular}

Tabel 2. Penggunaan chemical reverse demulsifier

\begin{tabular}{|c|c|c|}
\hline \multirow[t]{2}{*}{ Bulan } & \multicolumn{2}{|c|}{ Jumlah } \\
\hline & Liter & Drum \\
\hline Januari & 800 & 4 \\
\hline Februari & 400 & 3 \\
\hline Maret & 600 & 2 \\
\hline April & 2000 & 10 \\
\hline Mei & 600 & 3 \\
\hline Juni & 1200 & 6 \\
\hline Juli & 1600 & 8 \\
\hline Agustus & 1400 & 7 \\
\hline September & 800 & 4 \\
\hline Oktober & 1000 & 5 \\
\hline November & 1400 & 7 \\
\hline Desember & 800 & 4 \\
\hline Total & 12600 & 63 \\
\hline
\end{tabular}

Tabel 3. Pengadaan chemical demulsifier

\begin{tabular}{|c|c|c|}
\hline \multirow[t]{2}{*}{ Bulan } & \multicolumn{2}{|c|}{ Jumlah } \\
\hline & Liter & Drum \\
\hline $\begin{array}{l}\text { Januari } \\
\text { Februari }\end{array}$ & 2200 & 11 \\
\hline Maret & 2000 & 10 \\
\hline
\end{tabular}




\begin{tabular}{|l|l|l|}
\hline April & & \\
Mei & & \\
Juni & & \\
Juli & & \\
Agustus \\
$\begin{array}{l}\text { September } \\
\text { Oktober } \\
\text { November } \\
\text { Desember } \\
\text { Total }\end{array}$ & 2000 & 10 \\
\hline
\end{tabular}

Tabel 4. Pengadaan chemical reverse demulsifier

\begin{tabular}{|c|c|c|}
\hline \multirow[t]{2}{*}{ Bulan } & \multicolumn{2}{|c|}{ Jumlah } \\
\hline & Liter & Drum \\
\hline Januari & 2000 & 10 \\
\hline Februari & & \\
\hline Maret & 2000 & 10 \\
\hline April & & \\
\hline Mei & 4000 & 20 \\
\hline Juni & & \\
\hline Juli & & \\
\hline Agustus & 6000 & 30 \\
\hline September & & \\
\hline Oktober & & \\
\hline November & 6000 & 30 \\
\hline Desember & & \\
\hline Total & 20.000 & 100 \\
\hline
\end{tabular}

\section{ROP chemical demulsifier}

a. lead time: yaitu pemesanan yang dilakukan selama 14 hari

$\mathrm{LD}=14 / 30=0,46$ bulan

b. Pemakaian rata-rata

$\mathrm{AU}=7800 / 12$ bulan $=650$ liter $/$ bulan

c. Safety stock

$\mathrm{SS}=(100 \mathrm{~L}-650 \mathrm{~L} /$ bulan $) \times 0,46$ bulan $=161 \mathrm{~L}$

d. ROP

ROP $=0,46$ bulan $x 650 \mathrm{~L} /$ bulan $+161 \mathrm{~L}=460 \mathrm{~L}$

Jika pengadaan chemical demulsifier dilakukan setiap 3 bulan maka cara menghitungnya yaitu: pemakaian rata-rata sebulan x 3 bulan 650 liter x 3 bulan $=1950$ liter .

2. ROP chemical reverse demulsifier a. lead time: yaitu pemesanan yang dilakukan selama 14 hari

$\mathrm{LD}=14 / 30=0,46$ bulan

b. Pemakaian rata-rata

$\mathrm{AU}=12600 / 12$ bulan $=1050$ liter $/$ bulan c. Safety stock

$\mathrm{SS}=(2000 \mathrm{~L}-1050 \mathrm{~L} / \mathrm{bulan}) \times 0,46$ bulan $=437 \mathrm{~L}$

d. ROP

$\mathrm{ROP}=0,46$ bulan $\times 1050 \mathrm{~L} / \mathrm{bulan}+437 \mathrm{~L}=460$ $\mathrm{L}$

Jika pengadaan chemical demulsifier dilakukan setiap 3 bulan maka cara menghitungnya yaitu : pemakaian rata-rata sebulan $\times 3$ bulan 1050 liter $\times 3$ bulan $=3150$ liter.

\section{Re Order Point}

Dalam metode re order point hasilnya akhirnya adalah menentukan titik dimana akan kembali melakukan pemesanan material chemical yang dibutuhkan. Metode ini sangat cocok diaplikasikan karena salah satu alasannya adalah, perusahaan tidak memiliki pergudangan yang cukup luas untuk menyimpan stock yang banyak. Pergudangan yang dimiliki sekarang ini masih tergolong kecil jika dibandingkan dengan banyaknya material-material yang dimiliki.

Data yang digunakan sebagai tolak ukur adalah data penggunaan material chemical di 2018. Hasil perhitungannya digunakan untuk pengadaan 2019. Metode re order point juga kita dapat mengetahui stock yang masih ada karena Sistem monitoring data penggunaan kita selalu tercatat setiap hari sampai mencapai re order point nya.

Dari hasil pengolahan data pada bab 4 diperoleh hasil re order point untuk chemcial demulsifier sebesar 460 liter dan untuk chemical revers demulsifier sebesar 920 liter, dari hasil tersebut dapat disimpulkan bahwa semakin tinggi pemakaian rata-rata perbulan maka semakin tinggi pula titik ROP nya. Hal tersebut diperoleh dari jumlah pemakaian rata-rata perbulan untuk chemical demulsifier 650 liter/bulan dan titik ROP nya 460 liter, sedangkan untuk chemical revers demulsifier pemakaian rata-rata perbulannya 1050 liter/bulan dan titik ROP nya 920 liter. Apabila perusahaan memesan chemical kurang dari 460 liter dan 920 liter maka akan berdampak pada terjadinya kekurangan chemical saat produksi berlangsung. Jika perusahaan 

dalam Bidang Teknik Industri

memesan chemical pada titik lebih dari 460 liter dan 920 liter maka akan berdampak pada menumpuknya stock yang ada dan mengakibatkan tidak muatnya gudang peyimpanan.

Jika persediaan chemical demulsifier tersisa pada angka tersebut, maka perusahaan harus melakukan order kembali untuk menggantikan persediaan yang telah digunakan. Jika titik pemesanannya ditetapkan terlalu rendah maka persediaan akan habis sebelum persediaan pengganti diterima sehingga operasi dapat terganggu. Namun, jika titik pemesanan yang ditetapkan terlalu tinggi maka persediaan baru sudah datang, sedangkan persediaan digudang masih banyak. Keadaan ini mengakibatkan pemborosan biaya dan kelebihan muatan di gudang. Sehingga, untuk menentukan titik pemesanan yang baik mesti digunakan rumus re order point. Selama ini pengadaan dilakukan dengan perkiraan saja sehingga berdampak pada kelebihan stock yang berada digudang.

\section{Safety Stock}

Safety stock yaitu material yang harus selalu tersedia dalam gudang yang berfungsi sebagai pengaman untuk mengantisipasi keadaan dimana terjadi kehabisan stok selama lead time. Dari hasil pengolahan data pada bab 4 diperoleh safety stok untuk chemical demulsifier sebesar 161 liter dan chemical revers demulsifier sebesar 437 liter. Angka tersebut menunjukkan bahwa semakin tinggi pemakaian maksimum pada periode tertentu dan pemakaian rata-rata perbulan maka akan semakin tinggi angka safety stock nya. Hal tersebut diperoleh dari data pemakaian maksimum 1000 liter dan pemakain rata-rata sebulan 650 liter untuk chemical demulsifier maka safety stock nya diperoleh 161 liter. Sedangkan pemakaian maksimum dan pemakain rata-rata perbulan chemical demulsifier diperoleh 2000 liter dan 1050 liter maka safety stock nya sebesar 437 liter.

Peran safety stok yaitu sebagai stok pengaman jika stok chemical habis selama waktu tunggu kedatangan pemesaan kembali, sehingga bisa digunakan stok pada safety stock agar tidak terganggunya proses operasi perusahaan. Safety stock juga berperan jika stock yang normal pada perusahaan tidak cukup untuk memenuhi proses operasi dikarenakan cehmical yang terkontaminasi dengan air dan terjadinya kebocoran pada penggunanan maka Safety stock bisa berperan penting pada kendala tersebut. Apabila tidak ada safety stock maka akan berdampak terganggunya proses operasi perusahaan jika terjadinya kendala diatas.

\section{Kesimpulan}

Adapun kesimpulan yang diperoleh adalah sebagai berikut :

ROP pada chemical di PT. SPR Langgak untuk jenis demulsifier adalah 460 liter, sedangkan untuk jenis revers demulsifier adalah 920 liter.

Safety stock pada chemical di PT. SPR Langgak untuk jenis demulsifier adalah 161 liter, sedangkan untuk jenis revers demulsifier adalah 437 liter.

\section{Daftar Pustaka}

[1] Amin, Mustaghfirin. 2014. Proses Produksi Migas 2. Jakarta: Kementrian Pendidikan dan Kebudayaan Republik Indonesia.

[2] Fatma, Erika \& Pulungan Dian Serena. 2018. Analisis Pengendalian Persediaan Menggunakan Metode Probabilistik dengan Kebijakan Backhorder dan Lost Sales. Jurnal Teknik Industri Vol 19 (1). Jakarta: Manajemen Logistik Industri Elektonika Politeknik APP Jakarta.

[3] Ikhwanina, Qoni'ah. 2017. Analisis Penentu Re Order Point (ROP) Kedelai untuk kelancaran Proses Produksi Tempe Pada Raja Tempe di Nganjuk Tahun 2015. Jurnal Simki-Ekonomic Vol 1 (04). Kediri : Fakultas Ekonomi Universitas Nusantara PGRI Kediri.

[4] Irwadi, Maulan. 2015. Penerapan Re Order Point Untuk Persediaan Bahan Baku Produksi Alat Pabrik Kelapa Sawit Pada PT. Swakarya Adhi Usaha Kabupaten Banyuasin. Jurnal Akuntasnsi Politeknik Sekayu Volume II (1). Banyuasin: Program Studi Akuntansi Politeknik Anika.

[5] Jacobus, Steyssi I.W., Sumarauw, Jacky S.B. 2018. Analisi Sistem Manajemen Pergudangan Pada CV. Pasific Indah Manado. Manado: Fakultas Ekonomi dan Bisnis Jurusan Manajemen Universitas Sam Ratulangi Manado.

[6] Kushartini, Dinni \& Almahdy, Indra. 2015. Sistem Persediaan Bahan Baku Produk Dispersant Di Industri Kimia. Jurnal Pasti Volume X (2). Jakarta : Jurusan Teknik Industri Universitas Mercu Buana.

[7] Muhsin, Ahmad \& Apriyani Noor. 2017. Analisis Pengendalian Bahan Baku Dengan Metode Ekonomic Order Quantity dan Kanban Pada PT Adywinsa Stamping 
Industries. Yogyakarta: Jurusan Teknik Industri Universitas Pembanguna Veteran Yogyakarta.

[8] Trivana, Diana Y, \& Lukmana, Tomi. 2015. Penerapan Metode EOQ dan ROP. Jurnal Teknik Informatika dan Sistem Informasi Volume 1 (3). Bandung: Teknik Informatika Universitas Kristen Maranatha.

[9] Putra, Muhammad Rizki Agung, dkk. 2015. Analisis Sistem Pengadaan Barang/Jasa Dalam Meningkatkan Pengendalian Intern. Jurnal Administrasi Bisnis Vol 2 (2). Malang: Fakultas Ilmu Administrasi Universitas Brawijaya Malang.

[10] Yani, Ari Soeti. 2016. Analisis Persediaan Bahan Baku Kalep dengan Metode Economis Order Quantity Dalam Mendukung Kelancaran Usaha Pada Industri Kecil Sepatu Diwilayah Kemayoran. Jakarta: Universitas 17 Agustus 1945 Jakarta. 